\title{
OS TRAÇOS ESTÉTICOS NO TEATRO ÁUREO BARROCO E SUA VOCAÇÃO ÉTICO-DOUTRINÁRIA EM LOPE DE VEGA E CALDERÓN
}

LOS TRAZOS ESTÉTICOS EN EL TEATRO ÁUREO BARROCO Y SU VOCACIÓN ÉTICO-DOCTRINARIA EN LOPE DE VEGA Y CALDERÓN

Carlos Giovani Dutra Del Castillo*

RESUMO: O período mais frutífero da literatura espanhola se desenvolveu entre os séculos XVI e XVII, dentro do conhecido "Século de Ouro" e que abrange o contexto histórico-literário do barroco. Este trabalho sintetiza um estudo sobre o auge do teatro barroco por meio de dois de seus principais expoentes: Lope de Vega e Calderón de la Barca. Dessa forma, o intuito é discutir os aspectos estéticos e éticos do barroco espanhol, dentro do gênero dramático desse período.

PALAVRAS-CHAVE: teatro barroco; ética; estética.
* giovanidelcastillo@gmail.com

Doutorando em História da Literatura pela Universidade Federal do Rio Grande (FURG).

RESUMEN: El período más fructífero de la literatura española se desarque abarca el contexto histórico literario del barroco. Este trabajo sinque abarca el contexto hy sus principals exponentes: Lope de Vegay Caldeŕn de la Bas. sus pripipa expre é aú esta forma, el proposito es disculir los aspectos estéticos y eticos

PALABRAS CLAVE: teatro barroco; ética; estética. 
1. O período tido como mais brilhante da literatura espanhola compreende, segundo especialistas, os últimos 30 anos do século XVI e os primeiros 30 do século XVII. Marca uma geração incontestável de autores: Migue de Cervantes, Lope de Vega, Calderón de la Barca, Quevedo Góngora, para se citar os mais representativos da época.

2. TRÍAS, El objeto de la estética, $\mathrm{p}$. 1555 .

\section{INTRODUÇÃO: A ESTÉTICA E A ÉTICA NOS ASPECTOS}

\section{LITERÁRIOS DO BARROCO}

Durante o chamado Século de Ouro ${ }^{1}$ da literatura espanhola, a estética barroca fazia parte e conformava seu a uge no teatro espanhol e, como veremos, os desdobramento do drama estiveram a serviço de uma ideologia pretensamente ética, aquiescida por múltiplos interesses, ligados às estâncias de poder social e político. Dessa forma, a ética ou a moralidade se confundia com o poder constituído e com as expressões da estética literária espa nhola, entre os séculos XVI e XVII.

Em termos de pensar a estética, no contexto em que propomos, segundo Manuel Trías, "[...] El objeto de la Estética, es, pues, una estructura cuya esencia está dada por la forma de la finalidad [...]". ${ }^{2}$ Por esse viés de pensamento, dentro do âmbito estrita mente literário da estética barroca, predominam diversas finalidades em relação ao seu estilo formal, dentre as quais: a exageração, os contrastes (a beleza - a fealdade, o trágico - cómico, a verdade - a mentira), os aspectos impressionistas e a intencionalidade de contestar, por meio da falta de equilíbrio (umas vezes se deforma a realidade e em outras, se idealiza e se embeleza). Já no que tange à temática, fruto de uma visão a marga da vida, se tratam assuntos como a sátira da vaidade humana, o amor como algo muitas vezes negativo, a a mbição, a fugacidade da vida (o "Tempus Fugit" que significa "passagem veloz em direção à morte"), a representação da existência, enquanto tea tro ou sonho, em que temos um reflexo realista e desiludido da vida, em uma constante luta para vencer a miséria da existência, na ótica dos autores barrocos.

De fato, a arte barroca, aplicada nas obras literárias, possui certo enredamento em suas expressões formais e temáticas se inter-relacionam bastante: denota um estilo feito de adornos e suntuosidade; uma composição centrada nos pequenos detalhes e um gosto pelo ornamento; o contraste, cujo teor se sintetiza pela intenção do autor barroco de manifestar o contrário ao equilíbrio, confronta a uniformidade renascentista, tendo como ideal acolher, em uma mesma composição, visões distintas e até antagônicas, ao falar de um mesmo tema; o exagerado pessimismo relativiza a vida e a estabelece e um contexto de dor, bem como a fuga da realidade física, numa vida encarada como uma sombra uma ficção na qual vivemos enga nados porque percebemos uma aparência e não a realidade efetiva das coisas há também uma atitude ascética e mística, que propicia e prega apartar-se do mundo e dedicar-se somente a pensar na outra vida, cujo teor se dedica a examinar o espiritual e o metafísico do ser humano. Em outras palavras, o impacto do ideal artístico barroco valoriza a distorção das formas, a concentração conceitual e a complexidade na expressão, 
3. HATZFELD. Estudos sobre o Barroco, p. 296. com a finalidade de perturbar e maravilhar ao leitor. O caráter burlesco e sa tírico é uma das faces barrocas que suaviza essa tensão entre os opostos e tal ótica de desilusão com a vida, pois o humor se manifesta como crítica social, numa forma de contrastar uma crua realidade, mediante uma boa risada. Um exemplo literário que se pauta no contraste, ocorreu na poesia barroca espanhola, através de duas correntes essenciais: o conceptismo e o culteranismo ou gongorismo; a mbas expressões de um mesmo propósito estético, visando a criação de formas artificiosas e complicadas

[...] desde meados do século XVI, há em todos os países europeus movimentos literários amaneirados, com tendência a um estilo extravagante, repleto de metáforas estranhas e alusões originais, de pinturas forçadas e contrastes paradoxais. Este estilo extremado se chamou, já desde o século XVII, como se sabe, na Espanha Culteranismo, Conceptismo e Gongorismo $[. . .]^{3}$

Os máximos representantes foram Francisco de Quevedo- conceptista- e Luis de Góngora- culteranista. Os conceptistas se preocupavam com a compreensão do pensamento, nos seus mínimos detalhes e minúcias. Para esse fim, utilizava m recursos retóricos como os paradoxos, as antíteses, as paronomásias, os contrastes, as elipses, o que torna o raciocínio a mbíguo, na busca de satisfazer a inteligência. Pelo contrário, a estética culteranista ou gongórica se centra na descrição das coisas. É frequente nela o uso de figuras da linguagem como a antíteses, a metonímia, o exagero do uso da metáfora, o simbolismo, a sinestesia, e também neologismos. Seu objetivo era trabalhar bastante com a linguagem mais formal, a qual já se observara no âmbito clássico, por meio da tragédia e da poesia épica:

O perspectivismo e o impressionismo representam as formas reflexas mais condensadas e simples. Numa refração prismática, os aspectos que se contemplam estão rodeados por um halo que os acompanha, os prolonga e lhes acrescenta possibilidades [...] para os barrocos aristotélicos, a tragédia contém todos os elementos da poesia épica. ${ }^{4}$

Além disso, tanto na poesia como na prosa os aspectos formais se destacam, tais como a repetição intencional, enqua nto figura de linguagem que evocaria uma espécie de eco: "Na Espanha, Dámaso Alonso faz alusão ao eco estilístico do Barroco, qualificando-o de "repetição constante" [...] Isto justifica o eco humorístico empregado tão frequentemente por Cervantes". ${ }^{5}$ De qualquer forma, a riqueza de elementos literários empregados por seus autores contemporâneos se concretiza pelo contraste, pela tensão e pelas dicotomias:
4. HATZFELD. Estudos sobre o Barroco, p. 91.

5. HATZFELD. Estudos sobre o Barroco, p. 95. 
6. HATZFELD. Estudos sobre $o$ Barroco, p. 97.
[...] o estilo barroco está dominado por uma suprema amálgama paradoxal do racional com o irracional. Suas formas de expressão, tão marcada mente antitética, culminam num paradoxo e contradição interior. Assim como o Renascimento [...] preconizava uma clareza racional sem mácula, a ContraReforma se declarou a favor do paradoxo divino do mistério e da fé, como algo superior ao raciocínio humano. Toda a inquietude do cristão que se esforça por encontrar o equilíbrio entre a razão e a fé, entre a graça e o livre arbítrio, entre a determinação da vontade e a paixão, está refletida num estilo que [...] se caracteriza pelo contraste entre o propósito e a realização entre o alto e o baixo, entre o externo e o interno.

Sobretudo, essa proximidade que contrasta razão e fé se correlaciona na estreita equivalência entre a estética barroca e a ética ou moralidade que a subjaz, conforme se exemplifica por meio de textos fundamentais, em termos de referência estética, tal como a Poética, de Aristóteles, teve para os autores daquele momento:

O caráter ascético do humanismo barroco se transforma numa nova chave para a catarse aristotélica, sobretudo nos grandes autores [...] A grande reforma das modas e costumes, o cuidado e a direção das almas e a generalização de um sistemático exame de consciência se refletem no aumento de importância que na épica e no drama adquire seu caráter purificador.
Na Antiguidade, a catarse aristotélica tinha como objeto que o homem conseguisse libertar-se da compaixão e do medo, forças igualmente negativas na medida em que entorpeciam a vida livre e descuidada, baseada na mesotes. ${ }^{7}$ Para o Barroco, a libertação do poder das paixões significa um estímulo para a prática da virtude, a superação das más inclinações e o despertar das boas. Supõe inclusive o cultivo de um temor gera do inferno [...] O leitor ou o espectador da tragédia e da "comédia artificiosa" barroca se ergue contra o vício e se apaixona pela virtude [...] porque vê o que é em contraste ao que deveria ser. A fusão do nível moral com o nível estético é típica do Barroco dos mestres. A preocupação moral, condição da excelência ética e estética das obras primas, vai até o ponto em que a perfeição moral se torna indispensável se a obra de arte há de produzir deleite [...] é preciso sempre sentir [...] uma repercussão moral. A perfeição da forma aristotélica [...] deve achar um eco na perfeição moral da obra. ${ }^{8}$

Portanto, o barroco espanhol se caracteriza por essa a málga ma de elementos estéticos e éticos (o conceito utilizado de ética ou moral é entendido como um conjunto de preceitos que regulam a uma sociedade na qual, muitas vezes, as normas religiosas costumam ditar comportamentos e atitudes aceitas pela maioria). Assim sendo, em consonância com grande parte dos estudiosos do Século de Ouro espanhol, a Espanha não só vivenciou um período
7. Na visão de Aristóteles (384 a.C.- 322 a.C.), o meio-termo (mesotês) é o caminho ético para moral não é emoção ou faculdade, mas disposição da alma. É a escolha justa, correta, feita com discernimento e prudência.

\section{HATZFELD. Estudos sobre o} Barroco, p. 88.

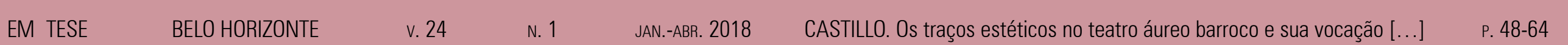


9. HATZFELD. Estudos sobre o Barroco, p. 319. áureo de sua cultura e de suas letras (estético), como foi divulgador de um amplo espectro de obras com esse intuito doutrinador (ético), principalmente as produzidas no período barroco, que a credenciam como país modelo, no que diz respeito a esse momento histórico-literá rio, diante do contexto europeu:

Estudando, finalmente, o problema da origem e da expansão do Barroco Literário, cheguei à conclusão de que a Espanha com a sua tradição [...] e as influências árabes posteriores, desenvolveu por si mesma certas manifestações precoces, as quais, por seu espírito e por sua forma, podemos chamar Barroco [...] e foi a Espanha, a nação contra-reformista, cató lica e barroca por excelência, que o amadureceu e o estendeu por toda a Europa [...] assumindo com justiça o papel de mestra literária da Europa, papel que, durante o Renascimento, havia pertencido à Itália. ${ }^{9}$

Desse modo, o cerne de reflexão sobre a estética barroca se sintetiza nos seus laços indiscutíveis com o poder ético e vigente da igreja católica, a qual instaurara uma contrarreforma, no intuito de prevalecer seus interesses, em face da crescente reforma protestante, durante o século XVI e XVII, pela Europa. Vamos analisar, na sequência, alguns aspectos correspondentes a dois dramaturgos do barroco que subsidiara m o teatro espa nhol com essa vertente ética, em suas respectivas obras dra máticas.

A estética e a ética doutrinária no tea tro espanhol barroco de Lope de Vega e Calderón de la Barca

Após falar-se brevemente de algumas características estéticas e éticas do barroco espanhol em sua veia literária, importa, para o objetivo deste trabalho, pensar especificamente no teatro espanhol, por meio de seu contexto social, político (ideológico) e religioso, elementos estes que abrangem a ética ou moralidade de uma dada sociedade, como a espanhola do século XVII. O estudioso Otto Maria Carpeaux, a través do seu ensaio Teatro e o Estado do Barroco, afirma que o tea tro sempre carregou, intrinsica mente, uma face ideológica, relacionada ao contexto político do momento histórico que o conecta:

Todo grande teatro [...] é por essência político. Não é por acaso que o teatro antigo e o teatro clássico de todas as nações modernas passam-se nas cortes dos reis. Para fazer bom teatro, é preciso saber o que é um rei. O teatro barroco gostou da história de Demetrius, que os jesuítas foram os primeiros a encenar e Lope de Vega representou no Gran Duque de Moscovia; a história deste príncipe Demetrius, de que não se sabia exatamente se era o Tzar dos Russos ou um impostor. Em todas as grandes tragédias do Barroco 
10. CARPEAUX. Teatro e Estado do Barroco, p. 11. trata-se de saber quem é o verdadeiro rei: Macbeth e o príncipe Segismundo, de La vida es sueño, suportam esta prova. $\mathrm{O}$ palco do teatro barroco significa verdadeiramente o mundo, o mundo político, mas também o mundo cósmico. A Hester de Pe. Jacobus Gretser S.J., representada em Munique com todos os refinamentos da montagem era a primeira peça de que "todo o mundo", o céu e o inferno inclusos, participava. Todo teatro barroco é o Gran teatro del mundo de Calderón só que a cortina às vezes tira a vista das forças cósmicas que decidem, no palco, o desuno humano. O teatro barroco declara-se conscientemente uma "comédia da vida" $[. . .]^{10}$

Segundo Carpeaux, o teatro barroco busca afastar-se do tea tro humanista do Renascimento e volta, então, a se aproximar de traços do que era o teatro medieval, com cenas que englobavam um mundo inteiro, ao representar o céu, a terra e o inferno. O palco barroco recobraria as origens de um teatro com ênfase ao universo cristão, por meio do poder político da Igreja. Com esse intuito, para representar ou encenar, dentro da visão dos autores barrocos, o artifício e a suntuosidade do cenário e dos elementos cênicos em si é abundante:

[...] artifícios da encenação barroca, sobretudo no tea tro dos jesuítas: há tempestades artificiais e fogos de artifício, máquinas que arrebatam personagens pelos ares, aparições de deuses nas nuvens, jatos d'água e de chamas infernais; havia proezas, como a divisão e a desaparição de nuvens, de que depois se esqueceu, e que a cena moderna não sabe mais reproduzir. Todos esses artifícios estão condicionados, ou antes são consequências das duas grandes inovações revolucionárias pelas quais o teatro barroco se distingue de todo teatro precedente: a perspectiva e a mudança de cena. As duas inovações correspondem às transformações de estilo, passando do Renascimento ao Barroco: a transição da "forma fechada" à "forma aberta", do "estilo plano" ao "estilo profundo"[...] A "profundidade" barroca corresponde à perspectiva; a "liberação das fronteiras" barroca corresponde à liberdade de mudar de cena. ${ }^{11}$

Através disso, a perspectiva, aludida por Carpeaux, é um a tributo do espaço, no qual o barroco o explora no intuito de que cada lugar esteja separado do outro, o que muda o ponto de vista ou perspectiva do espectador (algo inimaginável com o conceito aristotélico renascentista que pregava a unidade do espaço). É uma transformação radical na medida em que a cena se transmuta em um "mundo da ilusão", mundo que independe do preceito de factíve (mundo real). Dessa forma, os dra maturgos barrocos têm carta branca para criar mundos ilusórios, ou mundos dos sonhos, como atesta Carpeaux: "É por isso que o assunto 'sonho' é tão caro ao tea tro barroco que encontra aí sua
11. CARPEAUX. Teatro e Estado do Barroco, p. 13-14.
EM TESE
BELO HORIZONTE
v. 24
N. 1
JAN-ABR. 2018
CASTILLO. Os traços estéticos no teatro áureo barroco e sua vocação [..
P. 48-64 
12. CARPEAUX. Teatro e Estado do Barroco, p. 14.

13. Um dos principais dramaturgos espanhóis do barroco, nascido em Madri em 1600, vindo a falecer em 1681.

14. HATZFELD. Estudos sobre $o$ Barroco, p. 106-107. mais íntima substância [...]". ${ }^{12}$ A obra de Calderón de la Barca ${ }^{13}$ La Vida es sueño (1635), citada por Carpeaux, é um vívido exemplo da discussão metafísica que o protagonista Segismundo empreende quando questiona a realidade vigente. Nessa obra, a perspectiva, a ilusão e o sonho são três aspectos fundamentais do teatro barroco que se verificam constantemente na mesma:

[...] o sentido da imaginária de Calderón é o estabelecimento de uma relação entre as criaturas e seu criador. O constante intercâmbio entre estrelas e flores ou peixes e pássaros destaca a perspectiva no modo de olhar o mundo e a crença numa luz branca única [...] decomposta através das multicores lentes humanas. Este prisma está limitado pelos quatros elementos [...]: terra, água, fogo e ar. [...] a conhecidíssima e muito séria metaforização de Calderón quanto à velocidade de um cavalo. Trata-se de metáfora cheia de interiorismo barroco: Hipogrifo violento,/rayo sin llama,/ pájaro sin matriz, pez sin escama. (La Vida es sueño, I,I, p.215) [...] A visão prismática em lugar da direta é uma espécie de paradoxo [...] em estreita relação com a dra mática exploração de Calderón dos paradoxos cristãos: a morte é vida, a vida é sonho, a mortificação é prazer, o prazer é escravidão, o sacrifício, libertação [...] Em harmonia com o aspecto ideológico e moral, os sentimentos e as atitudes se dão também de uma forma paradoxal. ${ }^{14}$
A metáfora do sonho é explorada com louvor no teatro de Calderón, a ponto de levar à reflexão da antítese entre realidade e sonho, na evocação da vida como ilusão dos sentidos, tendo na desilusão (o chamado "desengaño" espanhol) o paradoxo, como pano de fundo:

O ponto mais elevado do paradoxo barroco é a convicção de que o mundo terreno é não apenas um sonho, mas também um engaño para o qual somente o reino espiritual oferece a possibilidade de um total desengaño. $\mathrm{O}$ aspecto filosófico e moral deste problema revela a total polarização de mentira e verdade, isto é, de ser e parecer [...] O engano para a vista interior, como a pseudomística segunda visão, o vislumbre, se dá quando uma atitude emocional evoca como real uma ilusão, em oposição aos fatos. ${ }^{15}$

Já ao se pensar no segundo aspecto trazido por Carpeaux - a mudança de cena - esta diz respeito ao maior dinamismo das ações e a conformação com tais aspectos metafísicos, como os vistos em Calderón:

O teatro propriamente barroco é uma "cena sucessiva", e, por isso, um teatro de movimento. Até mesmo um teatro de movimento excessivo. E como se um vento passasse pelas personagens do Barroco, como o vento que transforma os grupos plásticos dos altares barrocos em estatuaria agitada
15. HATZFELD. Estudos sobre $o$ Barroco, p. 108.
EM TESE
BELO HORIZONTE
v. 24
N. 1
JAN.-ABR. 2018
CASTILLO. Os traços estéticos no teatro áureo barroco e sua vocação [...]
P. $48-64$ 
16. CARPEAUX. Teatro e Estado do Barroco, p. 15-16.

17. O Concílio de Trento foi uma série de encontros ecumênicos da Igrej católica, desenvolvidos duran os anos 1545 e 1563 , com o objetivo de rever pontos da crença cristã e como reação à Reforma

18. CARPEAUX. Teatro e Estado do Barroco, p. 16-17.
[...] Esses dois termos resumem um teatro barroco: uma concepção metafísica expressa por um balé ilusionista. ${ }^{16}$

Além desses traços mais estruturais ou formais, não esqueçamos que a concepção metafísica a que Carpeaux se refere é a do típico espírito do homem barroco: moralista moralizante, ideologicamente empenhado a uma renovação moral do mundo ca tólico pelo Concilio de Trento. ${ }^{17} \mathrm{No}$ teatro barroco, todas as personagens são personificações do bem ou do mal:

As personagens da tragédia barroca não são elas próprias demônios, são vítimas do demônio [...] são antes mártires, vítimas de seu pessimismo excessivo. O tirano da tragédia barroca tem quase os traços de um santo, desesperado de sua salvação. É profundamente melancólico, pois conhece a maldade do mundo. Perde-se em sua melancolia, debate-se entre a incapacidade de decisão e tempestades afetivas [...] O drama barroco é pessimista. Os homens resistem penosamente ao mundo, por uma moral estóica, se não são salvos pela graça. ${ }^{18}$

Em síntese, as obras tea trais barrocas denotam um caráter doutrinador, no intuito de contornar possíveis atos de rebeldia ou questionamentos aos ensinamentos da igreja católica. A moral controla os atos do ser huma no e ele não possui o rela tivo livre arbítrio:
A tentação desempenha no teatro barroco o mesmo papel do Destino no teatro antigo: ela purifica pelo medo e humilhação. Por isso a tragédia barroca não tem herói trágico, no sentido dos Antigos. Walter Benjamin afirma mesmo que um verdadeiro herói trágico é impossível no Barroco: "O espírito da Contra-Reforma" faz os homens dependerem direta mente da intervenção celeste, o que torna impossível o conflito direto entre os homens, o conflito trágico. Benjamin explica, desse modo, a raridade de fins verdadeira mente trágicos no Barroco, e o final feliz de Vida es sueño é eloquente. ${ }^{19}$

O grande dilema, na visão do homem barroco é saber se e como ele pode se subtrair a essa decadência natural e pecadora. No que Carpeaux salienta com propriedade o caráter de marionetes dos personagens dos dramas barrocos: "[...] os que se entregam, voluntariamente, ao mundo, estão condenados [...] a ser marionetes, fantoches de suas paixões mundanas [...] E por isso que a cena barroca está repleta desses figurantes, até transformar-se em balé mudo." ${ }^{20}$ Contudo, no teatro barroco, paulatina mente o livre arbítrio passa a ser discutido, no que concerne à vontade humana. E quando ela é a nulada, isto significa que Deus ou o demônio venceu, mas pela livre decisão humana. Não é uma escravidão da vontade, mas simplesmente a dependência religiosa do homem. Mas se o homem rebaixa-se
19. CARPEAUX. Teatro e Estado do Barroco, p. 16-17.

20. CARPEAUX. Teatro e Estado do Barroco, p. 18.

EM TESE BELO HORIZONTE $\quad$ v. $24 \quad$ N. $1 \quad$ JAN.-ABr. 2018 CASTILLO. Os traços estéticos no teatro áureo barroco e sua vocação [...] P. 48-64


21. CARPEAUX. Teatro e Estado do Barroco, p. 19.

22. CARPEAUX. Teatro e Estado do Barroco, p. 20.

23. CARPEAUX. Teatro e Estado do Barroco, p. 22. vira marionete do demônio; e a submissão a Deus consiste em negação voluntária do mundo.

Dentro desse panorama, o drama barroco se configura em um mundo de grandes preocupações e de angústias religiosas. E a Contrarreforma pauta e afirma vigorosamente a vaidade ou orgulho do mundo, constituindo um dos temas preferidos do drama barroco: "Trata-se sempre da luta entre o mundo e o sobrenatural, trata-se sempre de uma decisão $[\ldots ..]{ }^{21}$ Outro assunto recorrente no tea tro barroco é a morte porqua nto, seu significado subverte o destino trágico tradicional das tragédias renascentistas, pois a morte pode ser uma redenção para um personagem que se arrependeu de seus pecados: "A tragédia barroca não tem necessidade de fim trágico. A própria morte é aí uma apoteose. A apoteose é a verdadeira conclusão do tea tro barroco". ${ }^{22}$ A tentação é também uma temática barroca que abrange esse teor moralista dentro do tea tro. Carpeaux assevera: "[...] tentação é assunto predileto do tea tro barroco, a tentação é assunto principal da história barroca: a tentação do vício, da heresia, da tirania; a luta dos Jesuítas, confessores dos reis, aí se impõe”. ${ }^{23}$ Embora quem atentasse contra os valores pregados pela igreja tivesse sua lição, sempre no desenlace da obra dramática barroca:

Los argumentos del Teatro Barroco Español están construidos sobre el principio de la justicia poética. La justicia poética es un principio literario y no un hecho de la experiencia. En la vida real, los malvados pueden prosperar y los virtuosos sufrir. Pero, en la literatura, durante el siglo XVII español se considerará adecuado que el crimen no quedara impune ni la virtud sin premio. El drama español también implícitamente afirma lo inverso: la necesidad del castigo del malvado; es decir, que nadie debería ser castigado y sufrir calamidades sin merecerlo. ${ }^{24}$

Analisar a conjetura dramática do tea tro espanhol, dentro do período áureo barroco, requer o estudo de um dos seus principais dramaturgos: Lope de Veja, ${ }^{25}$ quem era considerado o mestre dos principais autores dramáticos daqueles tempos e criador de la comedia nueva. O termo "comédia”, naquele momento era sinônimo de qualquer obra teatral, seja ela mais dramática ou cômica. Ele é considerado o criador do tea tro espanhol moderno graças a uma inovadora fórmula dramática, expressa em sua obra El Arte nuevo de hacer comedias (1609):

Se habla de la comedia del Siglo de Oro porque los dramaturgos emplearon este término, En realidad se trata de comedias, tragicomedias o tragedias. Apoyándose en ejemplos tomados en su mayor parte del Siglo de Oro, el Diccionario de Autoridades resume más de un siglo de uso nacional del vocablo Comedia: obra hecha para el teatro, donde se
24. VALDERRAMA. El teatro barroco en España y sus características, $\mathrm{p}$. 349.

25. Félix Lope de Vega y Carpio (1562 - 1635) foi um dramaturgo, autor de peças teatrais e poeta espanhol.

EM TESE BELO HORIZONTE $\quad$ v. $24 \quad$ N. $1 \quad$ JAN.-ABr. 2018 CASTILLO. Os traços estéticos no teatro áureo barroco e sua vocação [...] P. 48-64


26. VALDERRAMA. El teatro barroco en España y sus características, $\mathrm{p}$. 348.

27. O primeiro ato é usado para a exposição inicial do conflito; o segundo ato centra-se no clímax ou momento de maior tensão da trama; e o terceiro ato se utiliza para a resolução da ação dramática.

28. São chamados de personagens tipos porque não se aprofunda neles os aspectos psicológicos; importa mais a ação do que caracterizá-los detalhadamente. Os personagens barrocos mais representativos são: o nobre, o rei, o cavaleiro ou vilão, o galã, a dama e o cômico ou bufão, quem normalmente é o criado ou confidente do galã. representaban antiguamente las acciones del pueblo y los sucesos de la vida común, pero hoy, según el estilo universal, se toma este nombre de comedia por toda suerte de poema dramático que se hace para representarse en el teatro, o sea comedia, tragedia o tragicomedia o pastoral. El primero que puso en España las comedias en método fue Lope de Vega en su composición El Arte Nuevo de Hacer Comedias (1609). ${ }^{26}$

A importância deste livro reside no fato de que o autor enumera as principais características que obra teatral deve ter como referência: rompe com a "lei das três unidades" do teatro clássico: unidade de ação, unidade de lugar e unidade de tempo; a divisão do tea tro clássico entre obras trágicas e cômicas é ignorada, começa-se a misturar aspectos de a mbas a separação clássica de 5 atos é revista e passa a ter 3 atos principais (podendo variar de 3 a 5 atos, no entanto), ${ }^{27}$ há uma variedade maior no estilo e nas falas dos personagens, cujas características são tipificadas, ${ }^{28}$ pois eles devem representar e falar de acordo à classe social a que pertencem (variando numa linguagem de mais culta para mais popular):

El teatro de Lope estaba en franca rebeldía frente a las minorías frustradas, partidarias de una lectura e interpretación demasiado rígida de la retórica y del respeto a la tradición grecolatina. Si bien que la polimetría abrumadora, la repartición de las escenas en lugares muy alejados y el salir los personajes en diferentes épocas de su vida era una larga serie de herejías contra la norma aristotélica, la visión nacionalista del tea tro de Lope de Vega no rompe con la esencia del canon grecolatino, formulada en las poéticas de Aristóteles y Horacio. Para dejar claras las diferencias y similitudes de su teatro, Lope se creyó en la necesidad de escribir una especie de justificación o de disculpa de su praxis. Es así que en 1609, a los cuarenta y siete años, Lope de Vega publica el Arte nuevo de hacer comedias en este tiempo, poema en endecasílabos sueltos (verso blanco), salteado de pareados para una academia literaria. Esta obra es inestimable para ver lo que él pensaba, en la cumbre de su madurez y de su facilidad creadora, sobre su teatro, sobre la comedia nueva española del Siglo de Oro. ${ }^{29}$

29. CELEDÓN. Aproximaciones al Arte

Essa obra também pontua questões mais específicas como, por exemplo, a maneira que as "comédias" serão versificadas, de acordo a determinadas situações. Ou seja, nas obras teatrais dessa época todas as comedias são escritas em verso embora, com o advento dos preceitos de Vega, sua métrica passa a variar ainda mais (em vez da uniformidade dos metros clássicos) e dependem da situação para serem empregadas, em face de determinados tipos de estrofes. A esse respeito Valderrama nos esclarece:

El verso es el modo de expresión dramáticos. Se utilizan sobretodo el octosílabo, metro natural del Castellano.

EM TESE BELO HORIZONTE $\quad$ v. $24 \quad$ N. $1 \quad$ JAN.-ABr. 2018 CASTILLO. Os traços estéticos no teatro áureo barroco e sua vocação [...] P. 48-64


30. CELEDÓN. Aproximaciones al Arte nuevo de hacer comedias de Lope de Vega, p. 350
Apa recen versos tradicionales; o italia nos en diversas combinaciones estróficas, siendo las más frecuentes las redondillas, romances, décimas, quintillas, silvas, sonetos y octavas. La rica polimetría busca la acomodación entre verso y situación [...] El lenguaje del drama y su forma es el resultado de la conjunción entre la calidad estética de la palabra y su capacidad de plasmación de lo real. El lenguaje debe divertir encantando. [...] El soliloquio o monólogo, que expresa la dialéctica interior del persona, su conflicto interior, el tenso debate de los valores del alma del personaje es un recurso teatral frecuente mente utilizado, siendo famoso el monólogo de Segismundo en La Vida es Sueño de Calderón de la Barca, nuestro Hamlet español. ${ }^{30}$

Dessa forma, o teatro barroco continha muitos elementos que o enriqueceram, se compa rado ao tea tro mais clássico. Sua variedade de composições, a partir de Lope de Vega, foi um fato relevante posto que ganhou em popularidade e é uma forma artística de propagandear o "ideal moral”, ao deixar de ser algo mais elitizado para ta mbém chegar a contextos sociais mais humildes ou populares, democratizando a arte dramática, tornando-a acessível a todas as capas sociais:

El teatro anima todos los festejos o diversiones, será la comedia, el auto sacramental, la tragedia, la zarzuela, la ópera, el ballet, la mascarada, los entremeses, la mojiganga, y la reunión y enlace de varias de estas formas teatrales. El teatro barroco tiene una voluntad integradora en cuanto a la mezcla de lo noble y lo humilde, mixtura de la música, la danza, la pintura y la escultura, síntesis de temas divertidos y profundos. El teatro adquiere su pleno carácter de espectáculo Se comienza a construir los primeros teatros en las grandes ciudades, locales fijos para las representaciones teatrales. ${ }^{31}$

Outro aspecto interessante diz respeito à cenografia na medida em que ela foi ficando cada vez mais complexa em sua concepção, ganhando elementos antes ignorados pelo tea tro renascentista. Além disso, historica mente, o tea tro barroco se dividia em três tipos, do ponto de vista social, ou seja, de acordo ao público a que atendia:

[...] Lope contaba en Madrid con tres tipos de teatro, el eclesiástico, el de Corte y el teatro público urbano. Los dos primeros montaban con gran riqueza escenográfica piezas para celebrar festividades o ceremonias religiosas o cortesanas. El teatro público se construyó en el Corral de Comedias. El teatro se construía en un patio de vecindad, cerrado por casas en cubierto con un techo [...] Los balcones y ventanas de las casas que daban sobre el patio o corral servían de palcos desde donde veía el espectáculo un público más selecto. [...] Las mujeres tenían su sitio en la cazuela, situada al final
31. CELEDON. Aproximaciones al Arte nuevo de hacer comedias de Lope de Vega, p. 347
EM TESE
BELO HORIZONTE
v. 24
N. 1
JAN.-ABR. 2018
CASTILLO. Os traços estéticos no teatro áureo barroco e sua vocação [...]
P. $48-64$ 
32. CELEDÓN. Aproximaciones al Arte nuevo de hacer comedias de Lope de Vega, p. 349. del patio [...] Solían durar dos horas como mínimo y -tres como máximo. La escenografía que va variando va haciéndose cada vez más complicada y elaborada. El escritor de teatro debe esforzarse por satisfacer el gusto de un público insaciable que sin otra diversión pide constantemente novedades. De ahí que se instale la machina o tramoya que permite cambiar de escenario, descender a los actores también desde arriba. La maquinaria teatral de esa época consistía en un juego de poleas, en una grúa muy sencilla, y en un artefacto a nejado con cuerdas [...] Eran "las apariencias" o apariciones furtivas y espectaculares, generalmente acompañadas de luces y ruidos [...] La tramoya servía para levantar, bajar y hacer volar actores, los escotillones y los animales mecánicos e infernales, venían de aquellas obras, y habían sido utilizados abundantemente para ilustrar la salida de Satán de los infiernos y la llegada de los ángeles del cielo. ${ }^{32}$

Já em relação às principais temáticas representadas, o teor religioso se reveste de vários elementos que o ajudam a estabelecer seu caráter doutrinador ou moralizante. Quer dizer, distintas temáticas são usadas como pano de fundo para esse objetivo principal:

Existe una pluralidad temática: Los dramaturgos buscan argumentos y asuntos en el inmenso arsenal de temas de la literatura contemporánea, medieval o antigua o en la circunstancia histórica de su tiempo. Buscan inspiración en la tradición épica medieval y en el romancero; en la historia española antigua y las crónicas; temas pastoriles, moriscos, caballerescos y mitológicos; temas procedentes de la literatura religiosa como asuntos bíblicos, misterios, vidas de santos, y por último temas extraídos del vivir contemporáneo políticos, religiosas, sociales, Puesto que cada autor se siente con el derecho de dar su opinión sobre los problemas de su tiempo por medio de su obra teatral. ${ }^{33}$

Assim, o tea tro barroco se inspira no princípio de certa liberdade artística, ou seja, nega a submeter-se às normas do tea tro clássico. A despeito de a liberdade de criar ser relativa porque os principais dramaturgos espanhóis da época estavam ligados ou subordinados aos grupos dominantes da sociedade espanhola e, portanto, tais autores atendiam a determinados interesses ideológicos, de manutenção desse sistema e por isso se buscavam motivos tradicionais e religiosos:

Los detentadores del poder no fueron ajenos al enorme potencial propagandístico que les ofrecía un medio que tenían práctica mente a su merced. Por tal motivo, era de esperar que fuera utilizado para llevar a cabo una campaña de difusión e impregnación de un contenido ideológico, por aquellos grupos dominantes y a su cabeza la monarquía, que tenían poder
33. CELEDÓN. Aproximaciones al Arte nuevo de hacer comedias de Lope de Vega, p. 348 
34. MORAGA. El teatro barroco, instrumento del poder. Aspectos parateatrales de la fiesta barroca. para utilizar en gran medida, o, mejor dicho, para hacer suyo, ese instrumento de control sobre las conciencias[...] Es obvio que eran los privilegiados del viejo sistema, los miembros de las clases dominantes tradicionalmente instaladas en ese nivel y aquellos que, por uno u otro vinculo, se movían a su servicio, los más interesados en mantener el orden recibido y reforzar su resistencia. Por ello, fueron éstos, y muy especialmente los escritores dependientes de grandes señores o incluso del rey -como Lope de Vega y Calderón de la Barca-, quienes perspicazmente optaron por la utilización del teatro a fin de llevar a cabo una extensa campaña a favor de los poderes establecidos y del régimen de intereses afecto a ellos. En ese sentido podemos afirmar que a falta de otro tipo de medio de comunicación afán a los intereses reales, el teatro, y con ello sus autores, fueron el mejor medio manipulador de masas con el que contaron las clases dominantes [...]Por último, el teatro barroco ofrece un mensaje subliminal para los discrepantes contra el sistema, cuyo número es grande, atemorizándoles, castigándoles, haciéndoles ver con sus propios ojos, en el bien visible espacio de la escena, cómo siempre se imponen el rey y el orden que en su figura culmina. El teatro, pues, era el gran aliado de la monarquía y del régimen del absolutismo monárquico-señorial en que aquélla descansa. ${ }^{34}$

Consequentemente, Calderón de la Barca e Lope de Vega foram dois propagandistas do ideal barroco de cunho moral e doutrinador das classes dominantes, ligadas a igreja e ao poder monárquico da época. Não obstante, é importante salientar que, mesmo com esse objetivo ideológico, isso não significa que é um teatro de teor unicamente nacionalista ou ligado só ao âmbito cultural do país. Isso porque muitos historiadores literários gosta $\mathrm{m}$ de enaltecer o lado mais nacionalista do tea tro espanhol, durante esse período do Século de Ouro, o que a crítica especializada mais recente rebate, como afirma Evangelina Rodriguez Cuadros:

Hacer historia del teatro, especialmente cuando se particulariza en un país, supone construir un gran relato de legitimación. Para el caso del teatro español del Siglo de Oro este rela to se ha enfrentado a dos factores relevantes: por un lado, su historiografía canónica [...] ha propiciado un marco específico de referencia bajo el concepto de teatro nacional; por otro, ese particular sentido de pertenencia lo ha hecho borroso (y hasta invisible) cuando se le ha tratado de incluir en la historia cultural europea o en una epistemología compartida sobre cómo contar dicha historia teatral. ${ }^{35}$

Ela acrescenta que pensar no tea tro áureo espanhol transcende questões ufanistas pelo simples fato de que os principais dramaturgos espanhóis desse período provaram, no transcorrer de diversas a nálises histórico-literárias e dos críticos do assunto, sua importância na literatura
35. CUADROS. Teatro español del siglo de oro: del canon inventado la historia contada, p. 247.
EM TESE
BELO HORIZONTE
v. 24
N. 1
JAN.-ABR. 2018
CASTILLO. Os traços estéticos no teatro áureo barroco e sua vocação [...]
P. $48-64$ 
36. CUADROS. Teatro español del siglo de oro: del canon inventado a la historia contada, p. 269.

37. Auto é uma composição teatral do subgênero da literatura dramática, surgida na ldade Média XII. De linguagem simples, os autos, em sua maioria, têm elementos cômicos e intenção moralizadora. Suas personagen simbolizam as virtudes, os pecados, ou representam anjos, demônios e santos.

38. FEDERICO. Historia de la literatura y del arte dramático en España. universal por seu refinamento em termos de composição teatral e, acima de tudo, ao se referir a Lope e Calderón "[...] se libera al teatro del Siglo de Oro de su total dependencia del contenido temático para llevarlo al territorio de la teatralidad o la metateatralidad. La vieja antinomia Lope vs. Calderón se mide en términos de práctica escénica". ${ }^{36}$ Tal fim de cunho pedagógico e que serve até de instrumento de controle social, não exime o talento e a criatividade de ditos dra maturgos espanhóis Calderón de la Barca é um dos principais discípulos de Lope de Vega e estava atento às novas técnicas teatrais, instituídas por seu mestre. Um exemplo da herança estilística, dentro do gênero dramático inovador deste autor comprova-se em Calderón, quando ele adotou o modelo dos autos ${ }^{37}$ de seu antecessor:

Calderón ha adoptado de ordinario la forma de los autos, que le legó Lope de Vega, (...) Aun cuando se repitan con frecuencia las mismas figuras, $y$ suceda lo mismo con ciertos giros y enlaces de ideas, no es dudable evitarlo, atendiendo a que todos los autos sacramentales estaban únicamente destinados a celebrar el dogma de la Transubstanciación, y ese objeto imponía, por condición precisa, que, en estos espectáculos de la fiesta del Corpus, fuesen idénticas sus ideas fundamentales. ${ }^{38}$

Sobre os autos Cuadros ta mbém comenta: "[...] los dramaturgos españoles fueron incluso más universales que Shakespeare puesto que a éste le faltó la dimensión de un teatro del rito, tan complejo y fascinante como el auto sacramental". ${ }^{39}$ Portanto, Calderón de la Barca compartilha questões estéticas do tea tro barroco com seu antecessor e as amplia a seu modo. Nas obras calderonianas, o uso do símbolo e das reflexões filosóficas é uma marca constante. Os monólogos e as metáforas são de cunho espiritual, refletem sobre a vida e a morte. Nesse sentido, em sua obra dramática No hay cosa como callar (1639), sintetiza uma riqueza dos subgêneros do drama, como salienta Carlos Mata Induráin:

Otro asunto muy interesante es la complicada y discutida adscripción genérica de "No hay cosa como callar": ¿comedia de capa y espada o drama serio?; y, muy en relación con lo anterior, la interpretación global del texto y de su desenlace: ¿final feliz, más o menos convencional, o no tan feliz, con un casamiento forzado y un desenlace que queda irresuelto $\mathrm{y}$ abre paso a una previsible tragedia futura? Creo que lo que ha suscitado las variadas interpretaciones y asimismo las distintas consideraciones genéricas de la pieza se deriva de la siguiente circunstancia: "No hay cosa como callar" es «externamente», esto es, en lo que se refiere a la ambientación (urbana, cercana al aquí y ahora del espectador del XVII), al enredo y a los elementos constructivos que maneja en el desarrollo de la acción, una comedia perfectamente asimilable al grupo de las de capa y espada. ${ }^{40}$
39. CUADROS. Teatro español del siglo de oro: del canon inventado a la historia contada, p. 271.
40. INDURÁIN. Llorar los ojos y callar Ios labios: La retórica del silencio en No hay cosa como callar, p. 262 
41. HATZFELD. Estudos sobre o Barroco, p. 65.
De qualquer forma, Calderón de la Barca foi considerado um grande dramaturgo não só pela crítica especializada quanto por seu apelo ao gosto popular. Outras obras suas demonstram sua transição de um tea tro inicialmente mais simbólico e aristocrático para um drama mais popular e realista:

Os amplos interesses verdadeiramente populares na Espanha impedem a decadência total do Barroco [...] Pode-se ver, no caso particular de Calderón, como ta mbém mudou seu gosto de alegórico para realista, e, ao mesmo tempo, de aristocrático para popular, entre as datas de La vida es sueño (1635) e de El Alcalde de Zalamea (1644). ${ }^{41}$

Conforme atesta Helmut Hatzfeld: "O gosto muitas vezes barroquístico de Calderón o une definitivamente a Quevedo contra a metáfora cultista e a favor da metáfora conceptista [...]". ${ }^{42}$ Sua riqueza dra mática gosta muito de explorar metáforas que faça $m$ refletir sobre a realidade vigente. Dentro desse contexto, outra característica imprescindível de Calderón é o jogo das ideias opostas, o contraste que alimenta a tensão tipicamente barroca:

Se o claro-escuro apresenta um aspecto de simbolismo teatral, o motivo se amplia no conceito de que o mundo inteiro é um cenário finito que reflete o infinito. Esta é uma das ideias favoritas de Calderón, que representa a vida como $O$ Grande Teatro do Mundo, no qual o próprio Deus atua como diretor de cena e os atores hão de representar seus respectivos papéis sem estarem muito seguros do seu êxito final. ${ }^{43}$

Portanto, Calderón de la Barca e Lope de Vega são partícipes ativos do contexto áureo tea tral da Espanha, entre os séculos XVI e XVII, configurados, como vimos, na estética barroca e na ética de teor institucional, ajustadas tanto pela igreja quanto pelo poder monárquico. Não havia na época maior máquina propagandista do que os espetáculos populares barrocos, montados conforme tais intenções específicas:

Cabe recordar que fue un teatro realizado bajo la consciencia de una recepción múltiple en un espacio diversificado Una recepción, si no interclasista sí lo suficientemente masiva como para requerir una eficaz regulación administrativa por parte del poder civil que no sólo fue censor sino impulsor de la conversión del teatro en industria cultural moderna. Lo cual, evidentemente, obliga también a discriminar la a mbigüedad de los mensajes de ese tea tro que se hace heterogéneo, en el sentido escénico, es decir, capaz de manejar los contenidos para que lleguen desde códigos diferentes a unos espectadores ejemplarmente instruidos en sus convenciones. El teatro español consideró los géneros dramáticos (por eso
43. HATZFELD Estudos sobre o Barroco, p. 80.
42. HATZFELD. Estudos sobre o Barroco, p. 69. 
44. CUADROS. Teatro español del siglo de oro: del canon inventado a la historia contada, p. 275. supo romper sus reglas) no como formulaciones ideológicas sino como laboratorios de experimentación artística de mundos posibles o contingentes. Los textos del Siglo de Oro -mal que les pese a los sociólogos de la historia- no son un documento revelador de lo nacional o lo nocional sino una construcción de sentido vulnerable que puede revelar escénicamente el hueco entre la retórica del poder y las acciones de las figuras de ese poder. Cabe, en fin, tomar nota de su legado posmoderno - no necesariamente de huraño pesimismo barroco- de la conciencia de meta- teatralidad y de hedonista confusión entre realidad y apariencias, vida y sueño que siembra [...]. ${ }^{44}$

Em suma, a despeito da indiscutível qualidade retórica e estética das obras dramáticas barrocas destes dramaturgos, elas também são produtos de tênues relações de controle, exercidas pelo poder monárquico e eclesiástico, em face do intuito de reforçar ideologicamente sua imagem de autoridade que deve ser respeitada, bem como dar plena observância às regras sociais estabelecidas. A questão ético-doutrinária se destaca e é um desdobramento natural haja vista que dela se depreende todo um arcabouço voltado para a manutenção do discurso hegemônico, a través do teatro á ureo espanhol. Além disso, como salienta Cuadros na citação acima, a qualidade de tais dra maturgos se testemunha, por exemplo, pelo legado deixado na pós-modernidade em relação ao jogo de aparências entre ficção e realidade e a ideia de se debruçar sobre seu próprio gênero, conforme se alude com a meta-teatralidade. Lope de Vega foi o precursor e Calderón de la Barca um fiel discípulo dos preceitos em voga nos palcos espanhóis barrocos, com vistas a entreter o público e, ao mesmo tempo, doutrinar sorrateiramente com os aspectos ideológicos da classe social dominante.

\section{REFERÊNCIAS}

CARPEAUX, Otto Maria. Teatro e Estado do Barroco. Disponível em: http://www.revistas.usp.br/eav/article/view/8579/10130. Acesso em 11/06/17.

\section{CELEDÓN, Esteban Reyes. Aproximaciones al Arte nuevo de}

hacer comedias de Lope de Vega. Disponível em: http://www. aitenso.net/textosycontextos.pdf. Acesso em 14/06/17.

CUADROS, Evangelina Rodriguez. Teatro español del siglo de oro: del canon inventado a la historia contada. Disponível em: https://www.cairn.info/revue-internationale-de-philosophie-20102-page-247.htm. Acesso em 13/06/17.

FEDERICO, Adolfo. Historia de la literatura y del arte dramático en España. Madrid: Colección de escritores castellanos, tomo V, 1887. Disponível em: http://www gutenberg.org/ files/37095/37095-h/37095-h.htm. Acesso em 08/12/14.

HATZFELD, Helmut. Estudos sobre o Barroco. São Paulo: Perspectiva, 1988.
EM TESE
BELO HORIZONTE
v. 24
N. 1
JAN.-ABB. 2018
CASTILLO. Os traços estéticos no teatro áureo barroco e sua vocação [...] 
INDURÁIN, Carlos Mata. Llorar los ojos y callar los labios:

a retórica del silencio en No hay cosa como callar. Anuario

calderoniano, Universidad de Navarra, 2010.

MORAGA, Angel Luis Rubio. El teatro barroco, instrumento del

poder. Aspectos parateatrales de la fiesta barroca. Disponível

em: http://www.revistalatinacs.org/a1999iab/111ateatro.htm.

Acesso em 14/06/17.

TRIAS, Manuel B. El objeto de la estética. Disponível em: http://

www.filosofia.org/aut/003/m49a1553.pdf. Acesso em 11 Mai.

2018

VALDERRAMA, Milena Cáceres. El teatro barroco en España

y sus características. Disponível em: http://dspace.unav.es/

bitstream/10171/18175/1/35 Caceres Valderrama.pdf-. Acesso

em 15/06/17

Recebido em: 15-05-2018

Aceito em: 26-08-2018. 